\title{
ON THE ORIGIN OF ECLOGITE AND WEBSTERITE PARAGENESES IN THE CRATONIC MANTLE, AND THEIR RELATIONSHIP TO TTG GRANITOID MAGMATISM
}

\author{
R.P. Rapp ${ }^{1}$, and N. Shimizu ${ }^{2}$ \\ ${ }^{1}$ Department of Geosciences and Mineral physics Institute, USA; ${ }^{2}$ Woods Hole Oceanographic Institution, USA.
}

\section{INTRODUCTION}

Understanding the genetic relationship between the Narich TTG (tonalite-trondhjemite-granodiorite) suite of granitoids comprising the earliest continental masses, and their deep roots or "keels" in the underlying mantle is crucial to the development of models for the origin and growth of the continents and the chemical evolution of the cratonic lithosphere. Archean TTG granitoids are thought to originate by partial melting of primitive (basaltic) oceanic crust in unison with some sort of recycling (subduction?) mechanism. Partial melting experiments on hydrous basalt at pressures of 1-4 GPa produce liquids that closely resemble Archean TTG, as well as certain modern-day arc magmas, known as adakites, which are relatively rare and occur in association with "hot" subduction zones (e.g., ridge subduction, or subduction of very young oceanic lithosphere). As such, the composition of early Archean granitoids may provide clues to the tectonic setting and magmatic processes that governed continent growth and craton evolution. In assimilation experiments in which these same TTG liquids are allowed to infiltrate and react with a layer of depleted or fertile peridotite, "hybridized" granitoid melts (Mg-diorite), compositionally comparable to late-Archean sanukitoids, form in equilibrium with garnet websteritic (garnet + orthopyroxene \pm clinopyroxene) reaction residues (Rapp et al., 1999). These experiments simulate melt-rock reaction across the slab-mantle wedge interface in a subduction zone setting, or, more generally, across the crust-mantle interface at the base of an evoloving Archean craton. Considered together, the experimental results from both basalt melting and peridotite assimilation experiments reveal a full compositional spectrum of granitoid liquids, ranging from pristine (low-Mg\#) TTG melts in equilibrium with eclogite residues, to hybridized high-Mg\# monzodiorite (sanukitoid) melts in equilibrium with garnet websterite residues. Both groups of granitoids have a common 'eclogite melting' origin, and a corresponding spectrum of crystalline residues of melting and melt-rock reaction, from eclogite to garnet websterite, are formed as well. We have used the ion microprobe to geochemically fingerprint, in terms of an array of trace elements (Ba, Rb,Th, U, Nb, Sr, Zr, Y, Cr, REEs), coexisting granitoid liquids, and crystalline residues of melting (eclogite) or melt-rock reaction (peridotite) in these experiments, generating mineral-melt partition coefficients relevant to partial melting and melt-rock reaction in the process. Because these measurements have been made at natural abundance levels, direct comparisons can be made between the experimental melts and Archean granitoids, including both TTG and sanukitoid compositions. Such comparisons give an indication of the extent to which the mantle was involved in the petrogenesis of Earth's early continental crust. Similarly, direct comparisons can also be made between the crystalline residues of melting (eclogites) and TTG melt-peridotite interaction (garnet websterite), and the corresponding xenoliths and diamond inclusion parageneses from the subcratonic mantle. These comparisons help establish a genetic link between the granitoids that comprise the cratons, and their roots in the underlying lithospheric mantle, complementing isotopic (e.g., Pearson et al., 1995) and seismic studies that indicate an intimate, long-term coupling between these two domains.

\section{EXPERIMENTAL COMPOSITIONS}

\section{MELT COMPOSITIONS}

Partial melting of hydrous basalt at pressures of 1-4 GPa produces liquids that in terms of major- and traceelement composition closely resemble Archean TTGs. We refer to these melts, which are in equilibrium with eclogitic residual assemblages with or without rutile, as "pristine TTG". Their major-element composition is characterized by relatively low $M g$-numbers (where $M g$-number $=$ molar $[\mathrm{Mg} /(\mathrm{Mg}+\mathrm{Fe})])$, high $\mathrm{SiO}_{2}$ contents $\left(65-72 \mathrm{wt} \% \mathrm{SiO}_{2}\right)$, and alumina saturation index $\mathrm{A} / \mathrm{CNK}=0.9-1.1$ (where $\mathrm{A} / \mathrm{CNK}$ is the molar ratio $\left.\left[\mathrm{Al}_{2} \mathrm{O}_{3} /\left(\mathrm{CaO}+\mathrm{Na}_{2} \mathrm{O}+\mathrm{K}_{2} \mathrm{O}\right)\right]\right)$. Hybridization of pristine TTG melts by reaction with peridotite mineral assemblages forms liquids with higher $M g$-numbers, and lower $\mathrm{SiO} 2$ contents and $\mathrm{A} / \mathrm{CNK}$ ratios. The assimilation reaction consumes a significant proportion of the initial liquid, as well as all of the olivine originally present in the peridotite, leaving a crystalline 
reaction residue that contains garnet, orthopyroxene, \pm clinopyroxene (i.e., garnet websterite). The trace element abundance patterns of hybridized TTG melts parallel those of their pristine counterparts, but at overall higher concentrations. The amount and composition of hybridized melt appears to be quite sensitive to the "effective" melt:rock ratio (Rapp et al., 1999), as are the proportions and compositions of the phases comprising the reaction residue (see below).

The major-element characteristics of hybridized TTG melts (including $M g$-number, wt $\% \mathrm{SiO}_{2}$, and $\mathrm{A} / \mathrm{CNK}$ ratio) are comparable to those of Late Archean sanukitoids from the Slave and Superior Provinces of Canada, suggesting that the origin of these granitoids is in some way related to partial melting of hydrous basalt, followed by interaction with mantle assemblages. However, it is not clear whether these compositional similarities reflect peridotite assimilation by TTG melts, or an origin for sanukitoids that involves partial melting of TTG metasomatized mantle. To answer this question, we have conducted several "nearliquidus" experiments on a typical Superior Province sanukitoid composition at $3.5 \mathrm{GPa}$. These experiments provide insights into the source mineralogy for sanukitoid magmas. In experiments conducted at 3.5$4.0 \mathrm{GPa}$ and $1100-1250^{\circ} \mathrm{C}$, crystalline phase assemblages consisting of $\mathrm{Mg}$-rich eclogite (at higher temperatures), and garnet pyroxenite (garnet + opx + cpx) at lower temperature coexist with high-Mg\# granitoid melts $(\mathrm{Mg \#}=55-60)$ containing 60-70 $\mathrm{wt} \%$ $\mathrm{SiO}_{2}$ (see Fig. 1 below). Several experiments were also conducted in which the sanukitoid melt was reacted with small amounts (10-25 wt $\%)$ of a natural depleted peridotite (see Rapp et al., 1999 for description); in order for assimilation to occur, it was necessary to "superheat" the sanukitoid above its "pure" liquidus temperature, as estimated from the earlier set of experiments. Depending on temperature, the nearliquidus assemblage contains $\mathrm{Mg}$-rich garnet, low$\mathrm{Na} 2 \mathrm{O}$ clinopyroxene, \pm orthopyroxene, which is similar to the reaction residues observed in the peridotite assimilation experiments with TTG melts. These results are not unambiguous, but do suggest that sanukitoids are the product of a "hybrid" source, and not directly mantle-derived. Yet they also indicate that the mantle was involved to some extent in the petrogenesis of these Late Archean granitoids.

From the experiments with the sanukitoid compositions (both near-liquidus and "superheated" assimilation

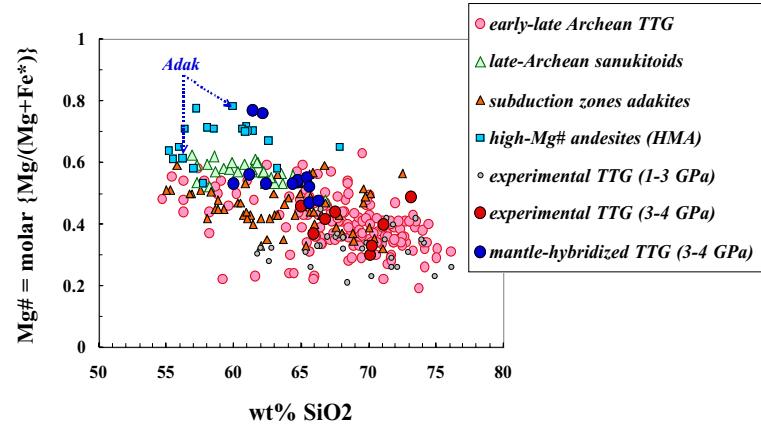

Figure 1. Mg-number versus $w t \% \mathrm{SiO}_{2}$ for experimental TTG melts at 1-4 GPa, and mantle-hybridized TTG at 3-4 GPa (this study), compared to early-mid Archean TTG and late Archean sanukitoids, and their modern counterparts, adakites and HMA, respectively, formed in modern subduction zones.

experiments), combined with the earlier melting experiments on metabasalt, a family of experimental liquids are revealed that are representative of "pristine" and variably "mantle-hybridized" granitoid melts that have their natural counterparts in Archean TTGs and sanukitoids. The full compositional continuum evident for natural samples of adakite and high-Mg andesite from modern subduction zones, early-late Archean granitoids, and the spectrum of experimental liquids, represents granitoids related to each other by a common origin, (e.g., "slab melting"?), with more magnesian members of the family having undergone some extent of interaction with peridotitic assemblages, most likely in a tectonic setting approximating a mantle wedge overlying subducting slabs. A family of crystalline assemblages ranging from eclogite to websterite were produced as well, corresponding to eclogitic and websteritic parageneses occurring as xenoliths and diamond inclusions (e.g., Stachel and Harris, 1997; Sobolev et al., 1998; Aulbach et al., 2002).

The concentrations of a selected group of trace elements were measured in the experimental liquids using the ion microprobe. Mantle-normalized trace element abundance patterns of the experimentallyproduced TTG family of granitoids, with or without accompanying assimilation of mantle peridotite, are shown in Fig. 2 below, where they are compared with the patterns for natural samples of TTG from the 3.4$3.6 \mathrm{Ga}$ old Kaapvaal (Hunter et al., 1992) and Zimbabwean Cratons (Kreissig et al., 2000). These data indicate an origin for early-mid Archean TTG by partial melting of hydrous basalt, leaving an eclogitic 
crystalline residue These results suggests limited involvement of mantle in the petrogenesis of TTG in the early-mid Archean.

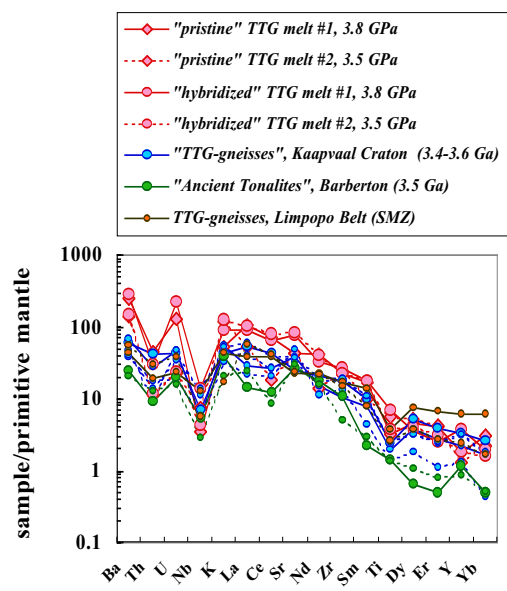

Figure 2. Primitive mantle normalized trace element abundance patterns for pristine TTG melts at 3-4 GPa, and their hybridized counterparts, formed by assimilation of small amounts of depleted peridotite, compared with earlymid Archean TTG from the Kaapvaal and Zimbabwean Cratons.

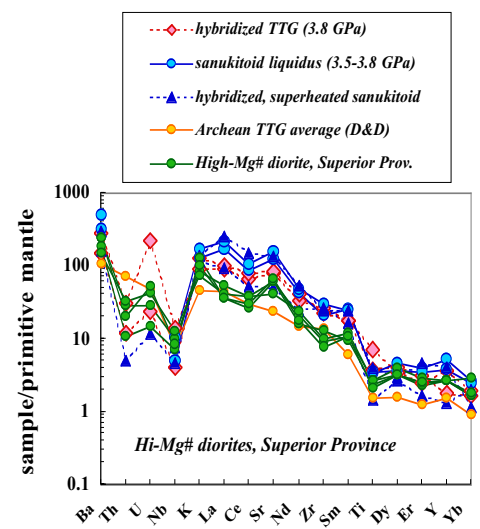

Figure 3. Primitive-mantle normalized trace-element abundance patterns for mantle-hybridized TTG, near-liquidus sanukitoid, and mantle-hybridized ("superheated") sanukitoid melts from experiments at 3-4 GPa, compared with average Archean TTG (Drummond and Defant, 1991; Mg\#=0.41), and high-Mg\# diorites from the Superior Province (Feng and Kerrich, 1997; MMGS suite, $\mathrm{Mg} \#=0.54-0.63$; $\mathrm{A} / \mathrm{CNK}=$ 0.89-0.95).

In contrast, the relatively high $\mathrm{Mg}$-numbers and $\mathrm{Cr}$ and $\mathrm{Ni}$ contents, and low $\mathrm{A} / \mathrm{CNK}$ ratios of Late Archean $(\sim 3.0-2.5 \mathrm{Ga}$ ago) sanukitoids from the Superior
Province (e.g., Feng and Kerrich, 1992) suggest that by this point in time, mantle involvement in granitoid petrogenesis was much more significant (Martin, 2002) (Fig. 3); the experimental evidence indicates that sanukitoids were not derived directly by mantle melting, but by interaction between (crustal-derived) TTG melts and the mantle. This conclusion is also borne out by the major-element comparisons in Fig. 1 above. TTG melt-peridotite interaction would most effectively occur in a tectonic setting approximating a mantle wedge overlying subducting slabs of oceanic lithosphere, with TTG liquids coming from dehydration melting of oceanic crust transformed to garnetamphibolite and eclogite. Melt-rock reaction across the slab-wedge interface would produce hybridized melts (sanukitoids) with intermediate $\mathrm{SiO}_{2}$ content and $\mathrm{A} / \mathrm{CNK}$ ratios less than 1.0, but possessing "primitive" characteristics like high $\mathrm{Mg \#}$, and high $\mathrm{Cr}$ and $\mathrm{Ni}$ abundances which could be mistaken as evidence for a mantle lineage. As shown by Fig. 3, these features would be coupled to strong enrichments in large-ion lithophile elements (LILEs) and relative depletions in high-field strength elements (HFSEs, such as $\mathrm{Nb}$ and Ta), heavy rare-earth elements (HREEs), and Y, features typical of TTG.

\section{Residual Mineral Compositions}

The compositional continuum apparent in Archean granitoids (TTG through sanukitoid) and mirrored by modern arc lavas associated with slab melting (adakites through HMA) is complemented by a similar compositional continuum in the residues of melting and TTG melt-peridotite reaction, which range from eclogite (garnet $+\mathrm{cpx}$ ) to garnet websterite (garnet + cpx + opx). These experimental crystalline assemblages in turn have their natural analogues in eclogitic and websteritic xenoliths and diamond inclusions erupted from the subcratonic mantle by kimberlites (e.g., Stachel and Harris, 1997; Sobolev et al., 1997, 1999; Jacob and Foley, 1999; Barth et al., 2001; Aulbach et al., 2002). The compositional continuum exhibited by both natural and experimental eclogite and garnet websterite samples is illustrated in Fig. 4, where proportions of $\mathrm{Ca}-\mathrm{Mg}-\mathrm{Fe}$ in garnet and clinopyroxene pairs in both eclogitic residues of melting and garnet websterite residues of TTG melt-peridotite interaction are shown. The experimental samples are compared with xenoliths and diamond inclusions of eclogite paragenesis from beneath the Siberian craton (Jacob and Foley, 1999; Sobolev et al., 1997), and for diamond in clusions of the websterite paragenesis from the Venetia Kimberlite in South Africa. The correlation between the major-element compositions of the experimental crystalline residues of partial melting and melt-rock reaction and natural samples of eclogite and 


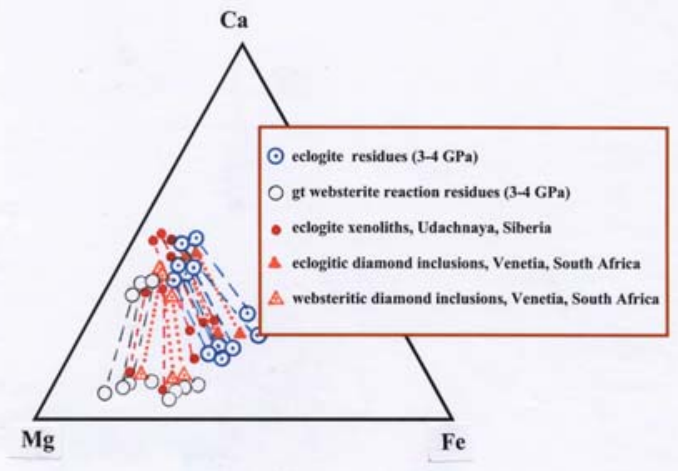

Figure 4. Molar proportions of $\mathrm{Ca}-\mathrm{Mg}-\mathrm{Fe}$ in coexisting garnet and clinopyroxene for experimental residues of melting (eclogite) and melt-peridotite reaction (gt-websterite), compared to xenoliths and diamond inclusions of eclogite and garnet websterite parageneses.

garnet websterite from the subcratonic mantle is substantiated by similarities in trace-element characteristics.

From ion microprobe analyses of coexisting melt and crystalline phases in our experiments, we can derive partition coefficients relevant to partial melting of eclogite and for TTG melt-peridotite interaction. In Figure 5, we show the experimentally determined D's for garnet and both pristine and mantle-hybridized TTG. It is clear from this data that the same or similar D's govern trace-element distribution during partial melting and melt-rock reaction.

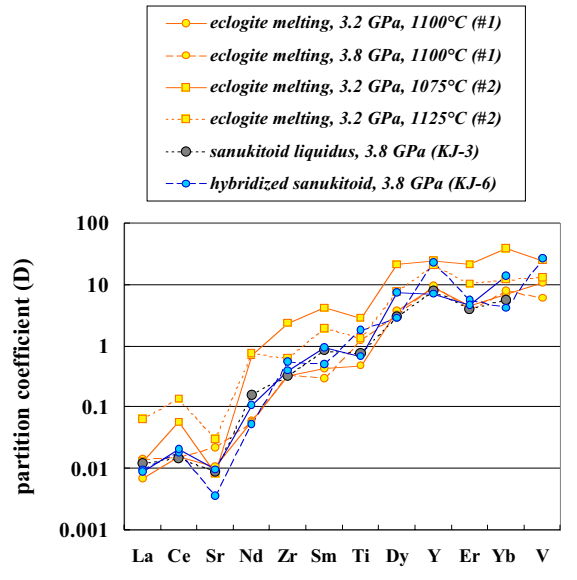

Figure 5. Garnet-melt partition coefficients for pristine and mantle-hybridized TTG melts at 3-4 GPa, and for sanukitoid melts at $3.8 \mathrm{GPa}$.

Trace-element analyses of clinopyroxene in our experimental assemblages is complicated by the small size of the crystals, but the limited data that we have obtained shows that, like garnet, the same (or similar) partition coefficients govern trace-element distribution between pristine- and mantle-hybridized TTG melts, and coexisting eclogitic and garnet-websteritic residues, respectively.

\section{DISCUSSION}

The compositional uniqueness of the cratonic lithosphere is well established on both geophysical and petrologic grounds (Boyd, 1989). Compositionally, cratonic mantle (as exemplified by 'low temperature peridotite xenoliths from the kaapvaal and Siberian cratons) is more magnesian than the oceanic mantle (with Mg\#'s of 91.5-93.5, and 90.5-91.5, respectively), and is relatively enriched mineralogically in modal enstatite. As argued by Kelemen et al. (1998), these features cannot be explained in terms of a single-stage process in which cratonic peridotites are residues from partial melting of primitive mantle to produce ultramafic (komatiitic) lavas in the Archean (e.g., Walter, 1998). Rather, a two-stage process is proposed in which high $\mathrm{Mg \# ,} \mathrm{low} \mathrm{modal} \mathrm{opx} \mathrm{peridotites} \mathrm{form} \mathrm{by}$ low-pressure $(<3.0 \mathrm{GPa})$ melting of primitive mantle, and these residues are subsequently enriched in opx by reaction with $\mathrm{SiO}_{2}$-rich liquids (Kelemen et al., 1998). The reaction between lherzolitic (peridotitic) mantle, enriched in olivine and clinopyroxene, and $\mathrm{SiO}_{2}$-rich melts (e.g., "granitic", or TTG), produces opx-enriched (harzburgitic) and websteritic peridotites by reactions of the general form: olivine $+\mathrm{SiO}_{2}$ (melt 1$)=\mathrm{Opx}+$ melt 2 (Kelemen et al., 1998). This reaction is essentially the same as the peridotite assimilation-TTG melt reactions described by Rapp et al. (1999), which consumed olivine and stabilized Opx in forming hybridized (i.e., high-Mg\# diorite or "sanukitoid") TTG melts. We propose that such reactions represent an important link between granitoids of the Archean continental crust and their roots in the underlying mantle, and may have general significance for the chemical evolution of the cratonic lithosphere.

Two main suites of diamond inclusions, with distinctive composition and mineralogy have been identified (peridotitic and eclogitic), representing (depending upon interpretation) mantle (ultramafic) or crustal (mafic, basaltic) pedigrees, respectively. More recently, a third diamond inclusion paragenesis (websteritic) has been recognized, transitional between the eclogitic and peridotitic parageneses. The websteritic suite is of particular importance for understanding crust-mantle interactions in continental roots, given the experimental evidence cited above for its role in TTG melt-peridotite reactions. Experiments to date have established that the composition of orthopyroxene formed in response to reactions between 

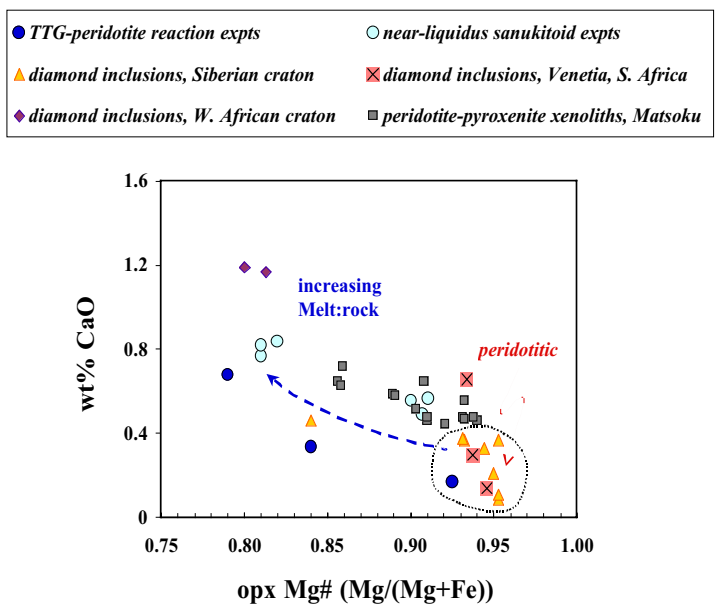

Figure 6. $M g$-number versus $\mathrm{wt} \% \mathrm{CaO}$ for orthopyroxene in garnet websterite reaction residues formed by interaction between TTG melts and depleted peridotite at 3.8 GPa (Rapp et al., 1999), and in near-liquidus sanukitoid melts reacted with peridotite at $3.8 \mathrm{GPa}$. Data for natural orthopyroxene in garnet websterite inclusions in diamond from the Mir kimberlite, Siberia (Sobolev et al., 1998), Venetia in South Africa (Aulbach et al., 2002), and W. Africa (Stachel et al., 1998), and peridotite-pyroxenite xenoliths from the Matsoku Pipe in Lesotho (Cox et al., 1973),.

TTG melts and depleted peridotite is controlled to some extent by the "effective" melt-to-rock ratio (Rapp et al., 1999), a rather cryptic term for a cryptic process. This relationship is illustrated by Fig. 6, and suggests that the composition of orthopyroxene in websterite and peridotite xenoliths and diamond inclusions may be an important clue in constraining the extent of crustmantle interactions in the cratonic lithosphere.

\section{REFERENCES}

Aulbach, S., Stachel, T., Viljoen, K.S., Brey, G.P. and Harris, J.W., 2002. Eclogitic and websteritic diamond sources beneath the Limpopo Belt- is slab melting the link? Contrib. Mineral. Petrol. 143, 56-70.

Barth, M.G., Rudnick, R.L., Horn, I., McDonough, W.F., Spicuzza, M.J., Valley, J.W., Haggerty, S.E., 2001. Geochemistry of xenolithic eclogites from West Africa, Part I: A link between low MgO eclogites and Archean crust formation. Geochim.. Cosmochim. Acta 65, 14991527.

Boyd, F.R., 1989. Compositional distinction between oceanic and cratonic lithosphere. Earth Planet. Sci. Lett. 96, 15-26.

Cox, K.G., Gurney, J.J., Harte, B., 1973. Xenoliths from the Matsoku Pipe. In Nixon, P.H. (Ed.) Cape and Transvaal, Cape Town. Lesotho Kimberlites. pp. 76-100.
Drummond, M.S., Defant, M.J., 1990. A model for trondhjemite-tonalite-dacite genesis and crustal growth via slab melting: Archean to modern examples. J. Geophys. Res. 95B, 121503-21521.

Feng, R., Kerrich, R., 1992. Geochemical evolution of granitoids from the Archeaen Abitibi Southern Volcanic Zone and the Pontiac subprovince, Superior Province, Canada: implications for tectonic history and source regions. Chemical Geol. 98, 23-70.

Hunter, D. R., Smith, D. G., Sleigh, D. W. W., 1992. Geochemical studies of Archean granitoid rocks in the Southeastern Kaapvaal Province: implications for crustal development. J. African Earth Sci. 15, 127-151.

Jacob, D.E., Foley, S.F., 1999. Evidence for Archean ocean crust with low high field strength element signature from diamondiferous eclogite xenoliths. Lithos. 48, 317-336.

Kelemen, P.B., Hart, S.R., Bernstein, S., 1998. Silica enrichment in the continental upper mantle via melt/rock reaction. Earth Planet. Sci. Lett. 164, 387-406.

Kreissig, K., Nagler, T.F., Kramers, J.D., van Reenen, D.D. \& Smit, C.A., 2000. An isotopic and geochemical study of the northern Kaapvaal Craton and the Southern Marginal Zone of the Limpopo Belt: are they juxtaposed terranes? Lithos 50, 1-25.

Martin, H., 2002. Secular changes in tomnalite-trondhjemitegranodiorite composition as markers of the progressive cooling of Earth. Geology 30, 319-322.

Pearson, D.G., Carlson, R.W., Shirey, S.B., Boyd, F.R., Nixon, P.H., 1995b. Stabilization of Archean lithospheric mantle: a Re-Os study of peridotite xenoliths from the Kaapvaal craton. Earth Planet. Sci. Lett. 134, 341-357.

Rapp, R.P., Shimizu, N., Norman, M.D., Applegate, G.S., 1999. Reaction between slab-derived melts and peridotite in the mantle wedge: experimental constraints at $3.8 \mathrm{GPa}$. Chemical Geol. 160, 335-356.

Sobolev N.V., Kaminsky F.V., Griffin W.L., Yefimova E.S., Win T.T., Ryan C.G., Botkunov, A.I., 1997. Mineral inclusions in diamonds from the Sputnik kimberlite pipe, Yakutia. Lithos 39, 135-157.

Sobolev, N.V., Sobolev, V.N., Snyder, G.A., Yefimova, E.S., Taylor, L.A., 1999. Significance of eclogitic and related parageneses of natural diamonds. International Geol. Rev. 41, 129-140.

Stachel T., Harris J.W., Brey G.P., 1998. Rare and unusual mineral inclusions in diamonds from Mwadui, Tanzania. Contrib Mineral Petrol. 132, 34-47.

Contact: RP Rapp, Department of Geosciences and Mineral Physics Institute, State University of New York, Stony Brook, New York USA 11794. E-mail: rrapp@notes.cc.sunsb.edu 